\title{
Outcomes of the proximal femur fractures repaired with half-pin devices as compared with various types of osteosynthesis
}

\author{
F.B. Salokhiddinov
}

Tashkent Medical Academy, Tashkent, the Republic of Uzbekistan

\begin{abstract}
Objective To review outcomes of the proximal femur fractures repaired with half-pin apparatus in comparison with various types of osteosynthesis. Material and methods The study enrolled 86 patients with proximal femur fractures treated at the general hospital of the Tashkent Medical Academy. Of these, 52 were females and 34 were males. The mean age of the participants was $54.1 \pm 1.1$ years (range, 22 to 92 years). The effectiveness of the treatment was evaluated depending on the treatment method used. The patients were divided into 3 groups: group I included 39 patients who underwent closed percutaneous osteosynthesis with Ilizarov wires; group II consisted of 29 patients who underwent osteosynthesis with bone plates; group III included 18 patients who underwent surgical treatment using the external half-pin fixator we developed. Results Outcomes were evaluated in 58 patients at one to two years. In group I, good results were rated as good obtained in $45.8 \%(n=11)$, as fair in $33.3 \%(n=8)$ and poor in $20.9 \%(n=5)$ of patients due to nonunited fracture, avascular necrosis of the femoral head and hip joint ankylosis. Group II showed $68.4 \%(n=12)$ good, $4(21 \%(n=4)$ fair and $10.5 \%(n=2)$ poor results. The latter occurred due to patient noncompliance and unauthorized early removal of the plaster cast. Group III demonstrated $73.4 \%(n=11)$ good, $13.3 \%(n=2)$ fair and $13.3 \%(n=2)$ poor outcomes. Patients with poor outcomes developed lesion of the femoral neck following a subcapital femoral neck fracture at 2 months of frame removal that healed with a $2.0 \mathrm{~cm}$ limb length discrepancy. Conclusion The external half-pin fixator offered could facilitate stable bone fixation after reduction and gradual dynamic compression for successful bone healing. The bone fixation period with external half-pin fixation device was dependent on the fracture type and averaged to $4 \pm 1$ months in type A fracture and $5 \pm 1$ months in type B fractures. Fixation of the proximal femur fractures with half-pin fixation device allows stabilization of the general state of patients, easier postoperative care, prevention of secondary complications and early exercises for the adjacent joints. The technique offered can be a method of choice among the current technologies.

Keywords: treatment, fracture, femur, transosseous osteosynthesis, half-pin fixation device
\end{abstract}

\section{INTRODUCTION}

A proximal femur fracture is a severe injury. Patients presenting with hip fracture often have multiple comorbidities and complex care needs. Hip fracture patients can represent various perioperative challenges related to their significant comorbidity burden. Prolonged bed rest in patients with proximal femur fractures lead to catastrophic deterioration of health and complications due to forced bed regime (hypostatic pneumonia, thromboembolism, pressure sores, etc.). Approximately 1.3 million femoral neck fractures were reported worldwide in 1990, and this figure is expected to double by 2025 and to increase to about 4.5 million by 2050 [1]. This is one of the most common and most significant fracture in terms of morbidity, mortality and socioeconomic impact. Overall mortality rates hover at $36 \%$ due to effects of associated comorbiditis during the first year after injury and $41 \%$ to $47 \%$ at 2 to 3 years $[2,3]$. Nonoperative treatment of hip fractures in adults is an exception. With the available surgical stabilization techniques, numerous studies support the advantage of surgical therapy in terms of morbidity, mortality and functional outcome. Minimally invasive surgical treatment is associated with reduced operating time, lower intraoperative blood loss and the possibility of performing the operation without general anesthesia. Surgical management followed by early mobilization is the treatment of choice for hip fractures in patients of any age. Co-occurring conditions (cardiovascular diseases, respiratory failure, decompensated diabetes mellitus, deep vein thrombosis of the lower limbs) contribute to the morbidity and mortality in all stages of surgical treatment. The goal of early surgical treatment of the proximal femur fractures is stable, anatomic fixation, allowing mobilization as soon as possible with lower complication rate [4]. Despite the advances in arthroplasty there is a variety of fixation techniques and osteosynthesis devices developed for hip fractures [5-8]. However, high cost of the fixators can hamper the use of the type of osteosynthesis to many patients.

Objective To review outcomes of the proximal femur fractures repaired with half-pin apparatus in comparison with various types of osteosynthesis.

\section{MATERIAL AND METHODS}

A half-pin device was developed for osteosynthesis of the proximal femur fractures and central dislocations of the femoral head (FAP patent No. 01180 of 2016) for better outcomes. The first module was designed for 
osteosynthesis of diaphyseal fractures of lower limbs [9]. The device (Fig. 1) for the treatment of the proximal femur fractures and central dislocations of the femoral head can be used as follows. Closed reduction of the femoral fracture is performed on an orthopaedic table using $\mathrm{C}$-arm image intensifier or serial radiographs. The device is assembled of arches (1) with holes for threaded rods (2) and applied to the injured segment. With the bone reduced proximally a Kirschner wire (No. 81/82353 registered with the State Register of Medical Devices) is drilled in the femoral neck using $\mathrm{C}$-arm to be a guide to form a canal. A Shanz screw (3) is inserted after predrilling with a cannulated cutter and fixed to the the cylindrical coupling (4). Another two Shanz screws (3) are placed parallel to the first screw along the femoral neck axis after predrilling. The fixator is fixed in the slots (5) of the arc plate (6) using U-shaped threaded rods (7). Two pairs of Shanz screws (3) are placed obliquely in the upper third and middle third of the femur and fixed to the threaded rods (2) using brackets (8) for bone stabilization. Additional pairs of Shanz screws (3) can be inserted over the acetabulum for marginal fractures of the acetabular roof. Permission for clinical use of the half-pin device offered was obtained from the relevant research ethics committee No. 6/2019 of 22.05.2019).

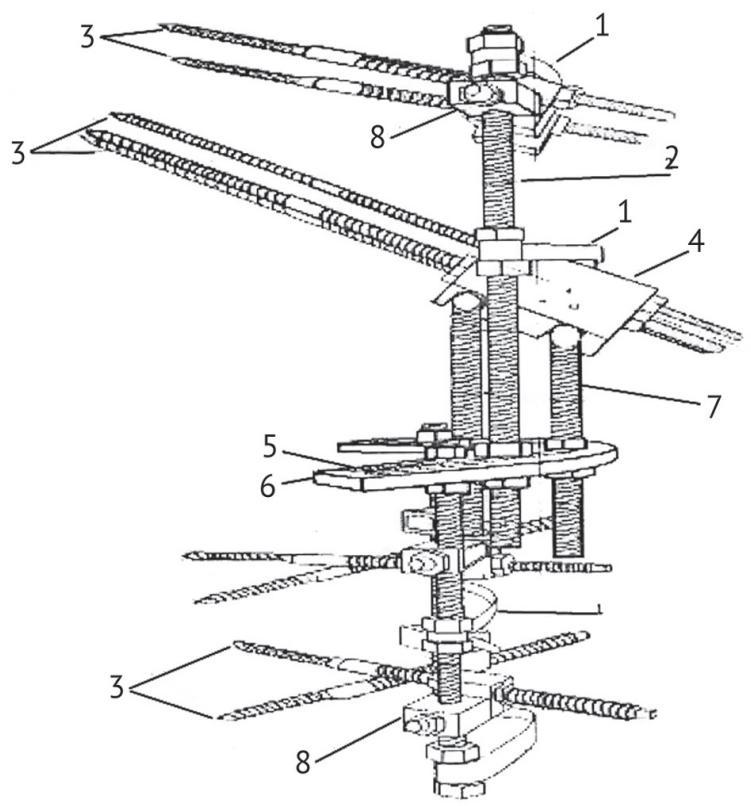

Fig. 1 Diagram of the half-pin device for osteosynthesis of the proximal femur fractures and central dislocations of the femoral head
The study enrolled 86 patients with proximal femur fractures treated at the general hospital of the Tashkent Medical Academy between 2016 and 2018. There were 52 females and 34 male patients. The mean age of the participants was $54.1 \pm 1.1$ years (range, 22 to 92 years). Fractures resulted from road traffic accidents $(\mathrm{n}=28 ; 32.6 \%)$, an injury sustained at home $(\mathrm{n}=41 ; 47.7 \%)$ and industrial injuries $(\mathrm{n}=17 ; 19.7 \%)$. The fractures were grouped according to the $2018 \mathrm{AO} / \mathrm{ASIF}$ classification [10] and included types 31A1 AO/ASIF $(\mathrm{n}=35)$, $31 \mathrm{~A} 2(\mathrm{n}=18), 31 \mathrm{~A} 3(\mathrm{n}=2), 31 \mathrm{~B} 1(\mathrm{n}=4), 31 \mathrm{~B} 2$ $(\mathrm{n}=8)$ and 31B3 $(\mathrm{n}=19)$. Patients were diagnosed with multiple injuries $(n=18)$ including femoral fractures combined with Smith fracture $(n=12)$, humerus fracture $(n=4)$ and ischial fracture $(n=2)$. Most of the patients had comorbid conditions (diabetes mellitus, cardiovascular diseases, arthritis, overweight, etc.). The effectiveness of the treatment was evaluated depending on the treatment method used. The patients were divided into 3 groups (Table 1); group I included 39 patients who underwent closed percutaneous osteosynthesis with a bundle of Ilizarov wires. The fractures of group I were classified as type $\mathrm{A}(\mathrm{n}=24 ; 61.5 \%)$ and type B $(\mathrm{n}=15 ; 38.5 \%)$. Of the 39 patients, $23(59 \%)$ were males and $16(41 \%)$ were females. There were $32(82 \%)$ patients aged $22-60$ years and 7 patients $(28 \%)$ aged 60 years and older. Group II consisted of 29 patients who underwent osteosynthesis with bone plates (Bakicharov, AO, ChM). The fractures were classified as type $A(n=20 ; 68.95 \%)$ and type $\mathrm{B}(\mathrm{n}=9 ; 31.05 \%)$. There were $19(65.5 \%)$ male and $10(34.5 \%)$ female patients. Of the 29 patients, there were $17(58.6 \%)$ patients aged 22-60 years and 12 patients $(41.4 \%)$ aged 60 years and older. Group III included 18 patients who underwent surgical treatment using the external half-pin fixator we developed. The fractures were classified as type A $(\mathrm{n}=11 ; 61.15 \%)$ and type $\mathrm{B}(\mathrm{n}=7 ; 38.85 \%)$. There were $12(66.7 \%)$ male and $6(33.3 \%)$ female patients. Of the 18 patients, there were $11(61.1 \%)$ patients aged $22-60$ years and 7 patients $(38.9 \%)$ aged 60 years and older.

Table 1

Distribution of patients with proximal femur fractures grouped according to the $2018 \mathrm{AO} / \mathrm{ASIF}$ classification

\begin{tabular}{|c|c|c|c|c|c|c|c|}
\hline \multirow{2}{*}{ Group } & \multicolumn{7}{|c|}{ Type } \\
\cline { 2 - 8 } & A1 & A2 & A3 & B1 & B2 & B3 & Total \\
\hline I & $18(46.1 \%)$ & $6(15.4 \%)$ & - & $1(2.6 \%)$ & $3(7.7 \%)$ & $11(28.2 \%)$ & $39(45.3 \%)$ \\
\hline II & $12(41.4 \%)$ & $7(24.1 \%)$ & $1(3.45 \%)$ & $1(3.45 \%)$ & $4(13.8 \%)$ & $4(13.8 \%)$ & $29(33.7 \%)$ \\
\hline III & $5(27.8 \%)$ & $5(27.8 \%)$ & $1(5.55 \%)$ & $2(11.1 \%)$ & $1(5.55 \%)$ & $4(22.2 \%)$ & $18(21 \%)$ \\
\hline Total & $35(40.7 \%)$ & $18(21 \%)$ & $2(2.3 \%)$ & $4(4.6 \%)$ & $8(9.3 \%)$ & $19(22.1 \%)$ & $86(100 \%)$ \\
\hline
\end{tabular}


A derotation splint to the ankle was applied for the patients after a clinical and radiological examination at the emergency department, Definitive osteosynthesis was performed within 3 days to 2 weeks after the injury with the patient's condition stabilized. Physical therapy was administered to prevent hypostatic pneumonia. Depending on the method of osteosynthesis applied, patients were encouraged to perform physical therapy, breathing exercises to prevent pressure ulcers after 2-to-3 postoperative days. Spica cast was applied to the fractured limb fixed with a bundle of Kirschner wires or a plate at 2 to 3 days of injury. Patients whose broken limb was fixed with half-pin fixation device were encouraged to perform quadriceps femoris exercises, passive and active exercises for the joints of the injured limb and were instructed how to get up out of bed, stand, ambulate using crutches or walkers. At 4 to 6 week, the patients could maintain full weightbearing on the operated limb fixed with external half-pin fixation device. Complication rate and the length of inpatient stay were evaluated to explore the effectiveness of different methods of osteosynthesis. Long-term outcomes were rated according to the Mattise scoring system [11].

\section{RESULTS}

Patients of group I $(\mathrm{n}=39)$ developed 41 complications (Table 2). Of these, patients with subcutaneous phlegmon $(\mathrm{n}=3)$ underwent debridement and antomicrobial therapy. Wires migrated and got broken $(\mathrm{n}=8)$ and were removed from the anterior abdominal wall $(\mathrm{n}=2)$. A wire migration resulted in bladder perforation $(n=1)$ at 45 days of fracture fixation with a bundle of wires. The wire was removed as an emergency with the urologist assistance, and the Pezzer catheter was applied. Other complications included secondary contractures of the hip and knee joints $(n=11)$, avascular necrosis of the femoral head $(n=2)$, lesion of the femoral neck or nonunion $(n=5)$ with no case of mortality. Delayed consolidation of the fracture was observed in 3 patients, and pressure ulcers developed in 4 cases. The mean period of bone consolidation was $6 \pm 1$ months. The average inpatient length was $5 \pm 1$ days. Three patients were re-admitted to have the complications addressed.

Patients of group II $(\mathrm{n}=29)$ developed 40 adverse events and complications. Patients with subcutaneous phlegmon $(\mathrm{n}=2)$ underwent debridement postoperatively. Transfusion of plasma and red blood cells was performed for hemoglobin blood level re-correction $(\mathrm{n}=6)$. The wound healed with secondary intention in 5 cases. Metal constructs broke up in 5 cases including Bakicharov plate $(n=2)$ and the ChM plate $(n=3)$.
Interlocking intramedullary nailing was performed for 2 patients. Three patients gave up, continued with nonoperative treatment and ended up with the fracture healed in varus alignment. Other complications included secondary contractures of the hip and knee joints $(n=8)$ due to spica cast, avascular necrosis of the femoral head $(n=2)$, lesion of the femoral neck or nonunion $(n=2)$ with no case of mortality. Delayed fracture consolidation was observed in 2 patients. The mean period of bone consolidation was $5.5 \pm 1$ months. The average inpatient length was $12 \pm 2.5$ days. Five patients were re-admitted to have the complications addressed.

Patients of group III $(n=18)$ developed 13 adverse events during outpatient treatment. Pin tract infection $(n=3)$ was treated by local use of antibiotics. Of these, one patient underwent removal of external fixation device at 11/2 months with the femoral neck united in varus alignment. Limited range of motion in the hip and knee joints (no more than $10^{\circ}$ ) was observed in 5 cases as compared with unaffected limb. Two patients sustained a femoral head fracture 31B1. 3 according to the AO/ ASIF classification, had the half-pin frame removed at 6 months with resultant lesion of the femoral neck and intermittent hip pain. The patients were recommended to walk with crutches with a moderate weight-beariung on the limb and radiologically developed healing of the femoral head with a shortening of $2.0 \mathrm{~cm}$.

Table 2

Local and general complications in patients who underwent different types of hip fracture fixation

\begin{tabular}{|c|c|c|c|}
\hline \multirow{2}{*}{ Type of complications } & \multicolumn{3}{|c|}{ Groups of patients } \\
\hline & Group I $(n=39)$ & Group II $(\mathrm{n}=29)$ & Group III $(n=18)$ \\
\hline Infected wound & - & 3 & - \\
\hline Postoperative hematoma & - & 2 & - \\
\hline Subcutaneous phlegmon & 3 & & \\
\hline Acute anemia & - & 6 & - \\
\hline Pin tract infection & - & - & 3 \\
\hline Wound healed by secondary intention & - & 5 & - \\
\hline Delayed fracture consolidation & 3 & 2 & 3 \\
\hline Avascular necrosis of the femoral head & 2 & 2 & - \\
\hline Lesion of the femoral neck, nonunion & 5 & 2 & 2 \\
\hline Metal construct migrated and broken & 8 & 5 & - \\
\hline Contracture of adjacent joints & 11 & 8 & 5 \\
\hline Hypostatic pneumonia & 5 & 3 & - \\
\hline Pressure ulcers & 4 & 2 & - \\
\hline
\end{tabular}


One patient was re-admitted due to repeated falls and developed severe pains in the injured limb. MSCT showed persistent bone and frame stability, and physical and radiological examination exhibited sciatic neuropathy treated successfully with novocaine blockade and a course of physiotherapy. Physical and radiological examination was crucial for the decision to have the frame removed with absent pain and edema on the involved limb, confident gait and the presence of radiological signs of fracture consolidation. The mean fixation time with frame on was $4.5 \pm 1$ month. The average inpatient period was $8 \pm 1$ days.

Long-term outcomes were evaluated in $58(67.4 \%)$ patients (Table 3$)$ at 1 to 2 years using the Mattise method. Results were rated as good in 11 $(45.8 \%)$, as fair in $8(33.3 \%)$ and poor in $5(20.9 \%)$ cases of group I. Poor outcomes were caused by nonunion, avascular necrosis of the femoral head and ankylosis of the hip joint. Group II demonstrated good outcomes in $13(68.4 \%)$ cases, fair in $4(21.1 \%)$ and poor in $2(10.5 \%)$ cases. Poor outcomes in Group II resulted from non-compliance and early unauthorized removal of the plaster cast. Group III demonstrated good outcomes in $11(73.4 \%)$ cases, fair in $2(13.3 \%)$ and poor in $2(13.3 \%)$ cases. Poor outcomes resulted from a subcapital fracture seen radiologically, and lesion of the femoral neck occurred at 2 months of the frame removal. The femoral head consolidated later with a $2.0 \mathrm{~cm}$ shortening of the lower limb.

Table 3

Long-term outcomes of hip fractures

\begin{tabular}{|l|c|c|c|}
\hline \multirow{2}{*}{$\begin{array}{c}\text { Outcomes } \\
\text { rated as }\end{array}$} & \multicolumn{3}{|c|}{ Groups of patients } \\
\cline { 2 - 4 } Group I $(\mathrm{n}=24)$ & Group II $(\mathrm{n}=19)$ & Group III $(\mathrm{n}=15)$ \\
\hline Fair & $11(45.8 \%)$ & $13(68.4 \%)$ & $11(73.4 \%)$ \\
\hline Poor & $8(33.3 \%)$ & $4(21.1 \%)$ & $2(13.3 \%)$ \\
\hline Total & $5(20.9 \%)$ & $2(10.5 \%)$ & $2(13.3 \%)$ \\
\hline
\end{tabular}

Clinical instance Patient T., born 1962, sustained an injury falling from the roof of a house from a height of about 2.5-3 meters. He presented with a combined closed craniocerebral injury, concussion of the brain, AO/ASIF31 B2. 1 closed subcapital displaced fracture of the right femur (Fig. 2). Osteosynthesis of the right-sided femoral neck was performed with a half-pin external fixation device of our own design at 2 days of injury following preoperative preparation(Fig. 3).Acourse of rehabilitation was administered for the patient after 3 postoperative days (Fig. 4). He could sit on the bed unassisted and walk with crutches. The postoperative period was uneventful and allowed the patient to be discharged from the hospital after 8 days with a satisfactory range of motion in the joints of the involved limb.
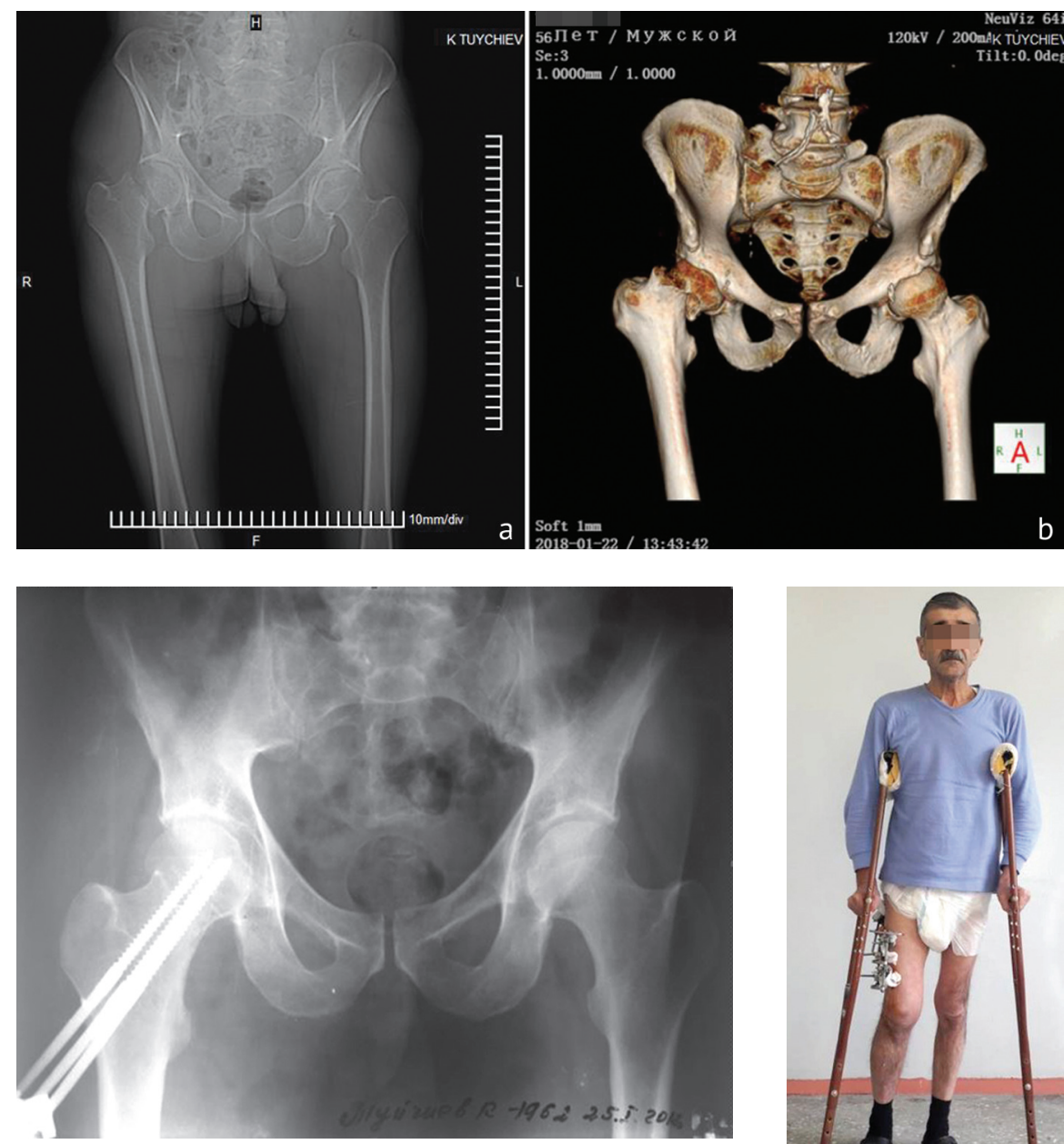

Fig. 3 Postoperative radiological view of the hip joints of patients T. born 1962

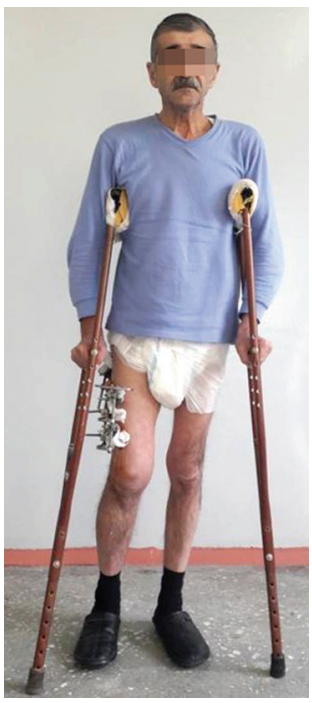

Fig. 4 Photograph of patient $\mathrm{T}$. born 19623 days post surgery
Fig. 2 Preoperative radiological view of the hip joints $(\boldsymbol{a})$ of patients T. born 1962 and 3D-reconstruction $(b)$ 
It took the bone 24 weeks to heal (Fig. 5) and the frame was dismantled. A radiograph at 1-year followup (Fig. 6) showed the restored anatomical structure with a $1.0 \mathrm{~cm}$ shortening of the involved limb. The

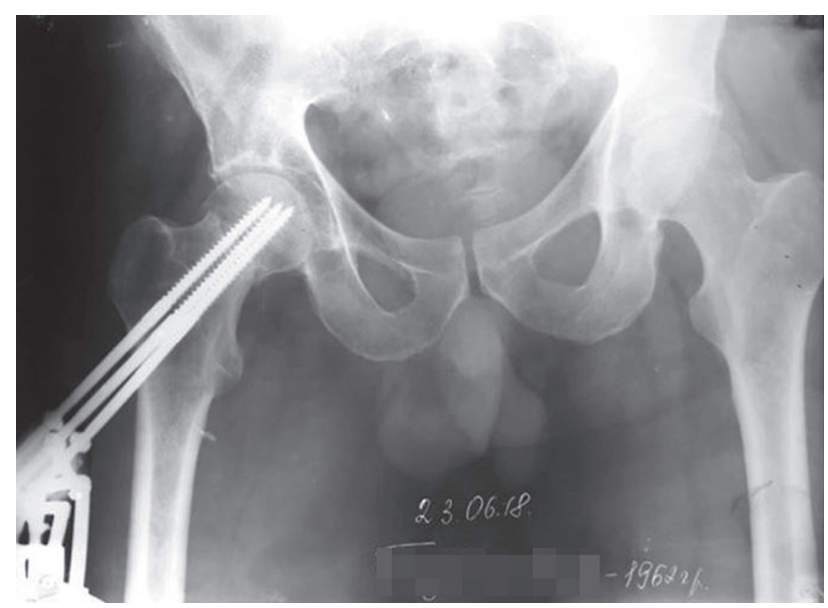

Fig. 5 Postoperative radiological view of the hip joints of patients T. born 1962 at 24 weeks post surgery patient presented no complaints at the gait, had no limping and could regain full range of motion in the hip, knee and ankle joints showing a good anatomical and functional result (Fig. 7).

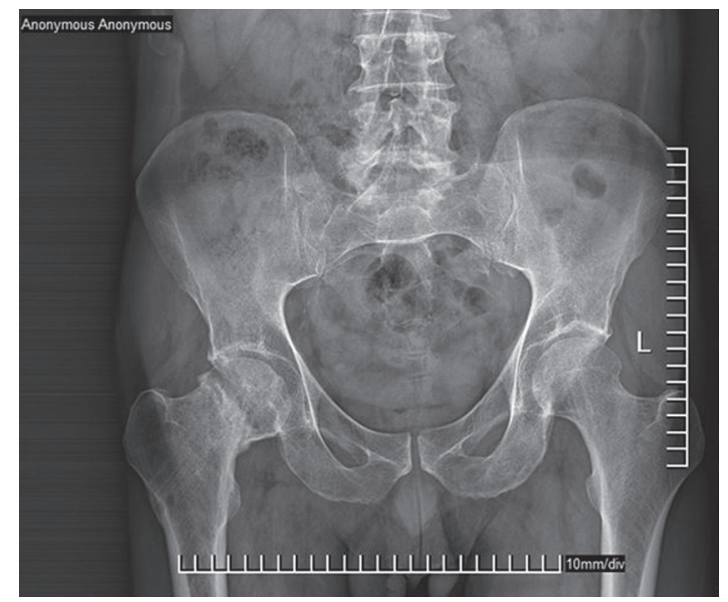

Fig. 6 Postoperative radiological view of the hip joints of patients T. born 1962 at one year post surgery
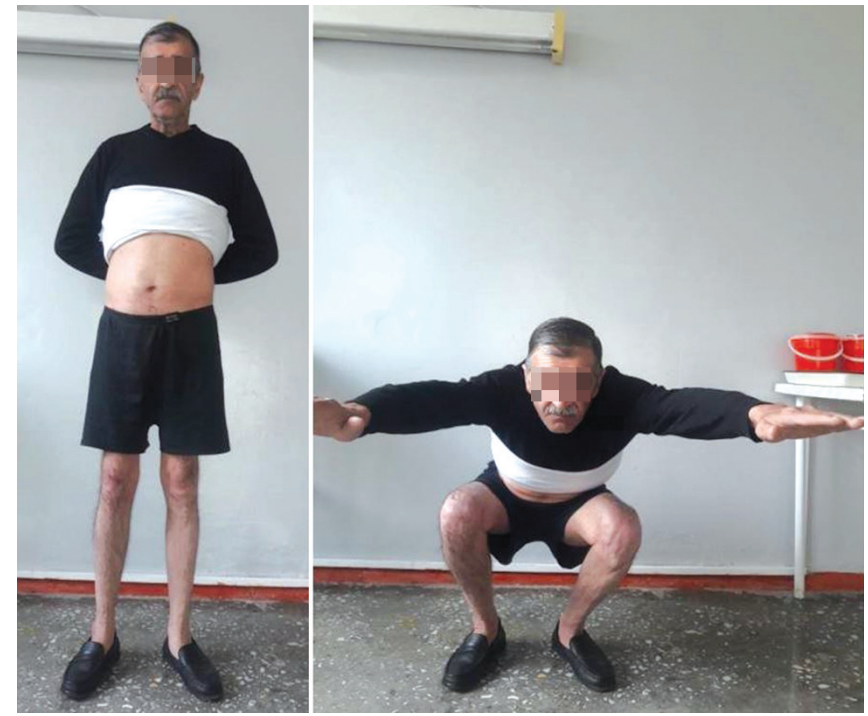

Fig. 7 Photograph of patient T. born 1962 showing functional result at a one-year follow-up

\section{DISCUSSION}

With the advantages of minimally invasive procedure and shorter operating time being characteristic of the hip fracture fixation with a bundle of wires, the method fails to provide rigid stability necessitating external immobilization and constant monitoring in comparison to plating and external fixation. The wire fixation technique can cause wires migrating in the hip joint and pelvis minor. Prolonged fixation with a spica cast can result in secondary contractures of the hip and knee joints. Plating is associated with open reduction and surgical exposure of the fracture site and can reduce biological resources for consolidation and require additional fixation with the cast leading to discomfort, adynamia and interefering with the patient's ability to perform self-care measures. In addition to that, prolonged fixation with a spica cast can result in secondary contractures of the hip and knee joints. The most serious complications include the loss of correction achieved due to lesion affecting the femoral head, screw migration and resultant impaired bone stability $[12,13]$.

A great number of different half-pin fixators were devised for osteosynthesis of proximal femur fractures $[5,10,14-16]$. The monolateral hybrid wire and half-pin fixator offered by A. S. Allakhverdiev and Yu. P. Soldatov for repair of femoral neck fractures [5] allowed a four-fold reduction of complications providing positive results in $95.7 \%$ of cases, while the fracture fixation with a bundle of wires attached to the Ilizarov frame could ensure favorable outcomes in $60.9 \%$. Therefore, fixation of femoral neck fractures with a bundle of wires 
can fail to provide good bone stability due to the lack of adequate compression at the fracture site. External fixation devices can be successfully used in emergency. The advantages include reliable stable fixation of the broken bone segments with minimal risk of secondary displacement. An important aspect of external fixation is the possibility of acute reduction and deformity correction in any plane. The use of the external fixation devices is accompanied by minimal trauma to the bone allowing optimization of reparative regeneration.

The advantages of the half-pin fixation device offered for osteosynthesis of the proximal femur include shorter operating time, reduced blood loss and minimal surgical trauma. It can be used in the first hours of injury. Early stable fixation of the proximal femur fractures helps to reduce pain which is an important antishock measure. The device provides correction of an abnormal femoral neck anteversion and the neck-to-shaft angle in subtrochanteric fractures. Bone compression can be provided throughout the treatment period with the frame on. The construct can be assembled depending on the fracture pattern facilitating patient's self-care, early ambulation and rehabilitation, preventing secondary complications and improving quality of life for patients.

\section{CONCLUSION}

The external half-pin fixator offered could Fixation of the proximal femur fractures with facilitate stable bone fixation after reduction and half-pin fixation device allows stabilization of the gradual dynamic compression for successful bone general state of patients, easier postoperative care, healing. The bone fixation period with external prevention of secondary complications and early half-pin fixation device was dependent on the exercises for the adjacent joints. The technique fracture type and averaged to $4 \pm 1$ months in type offered can be a method of choice among the A fracture and $5 \pm 1$ months in type B fractures. current technologies.

\section{REFERENCES}

1. Lomtatidze E.Sh., Volchenko D.V., Potseluiko S.V., Lomtatidze V.E., Kim N.I., Troshev Iu.V., Kruglov M.I., Popov D.P. Kompleksnaia otsenka rezultatov khirurgicheskogo lecheniia vnutrisustavnykh perelomov sheiki bedrennoi kosti [Complex evaluation of the results of treating intra-articular fractures of the femoral neck]. Vestnik Travmatologii i Ortopedii im. N.N. Priorova, 2005, no. 3, pp. 11-15. (in Russian)

2. Neverov V.A., Klimov A.V., Dultsev I.A. Perelomy sheiki bedra kak problema osteoporoza [Fractures of the femoral neck as a problem of osteoporosis]. III Rossiiskii Simpozium po Osteoporozu [III Russian Symposium on Osteporosis]. SPb., 2000 , pp. 141. (in Russian)

3. Matveev A.L., Minosov B.Sh., Minasov T.B., Nekhozhin A.V. Maloinvazivnaia khirurgicheskaia profilaktika perelomov sheiki bedrennoi kosti u lits pozhilogo vozrasta [Minimally invasive surgical prevention of the femoral neck fractures in the elderly subjects]. Materialy VIII Sezda travmatologov-ortopedov Uzbekistana "Aktualnye Voprosy Travmatologii i Ortopedii” [Proceedings of the VIII Congress of traumatologists-orthopedists of Uzbekistan "Relevant Problems of Traumatology and Orthopaedics"]. Tashkent, 2012, pp. 161-163. (in Russian)

4. Border J.R., Allgöwer M., Hanson S.T., Ruedi T.P., eds. Blunt multiple trauma: Comprehensive pathophysiology and care. New York, Marcel Dekker, 1990.

5. Allakhverdiev A.S., Soldatov Iu.P. Sravnitelnyi analiz rezultatov lecheniia bolnykh s perelomami sheiki bedrennoi kosti s primeneniem monolateralnogo spitse-sterzhnevogo ustroistva sobstvennoi konstruktsii i chreskostnykh fiksiruiushchikh spits [A comparative analysis of the results of treatment of patients with the femoral neck fractures using the monolateral wire-half-pin device of our own design and transosseous fixing wires]. Saratovskii Nauchno-Meditsinskii Zhurnal, 2014, vol. 10, no. 4, pp. 627635. (in Russian)

6. Belinov N.V., Bogomolov N.I., Ermakov V.S., Namokonov E.V. Zakrytyi kompressionnyi osteosintez pri perelomakh sheiki bedrennoi kosti sposobom avtora [Closed compression osteosynthesis for the femoral neck fractures by the author's method]. Vestnik Travmatologii i Ortopedii im. N.N. Priorova, 2005, no. 1, pp. 16-18. (in Russian)

7. Dubrov V.E., Iudin A.V., Shcherbakov I.M., Ragozin A.O., Matveev A.L., Ziuzin D.A., Saprykina K.A. Operativnoe lechenie perelomov sheiki bedrennoi kosti s ispolzovaniem dinamicheskogo derotatsionnogo osteosinteza [Surgical treatment of the femoral neck fractures using dynamic derotation osteosynthesis]. Vestnik Travmatologii i Ortopedii im. N.N. Priorova, 2016, no. 4, pp. 5-11. (in Russian)

8. Möllenhoff G., Walz M., Clasbrummel B., Muhr G. Schenkelhalsbruch. Osteosynthese oder welche Endoprothese ist indiziert? [Femoral neck fracture. Osteosynthesis or which endoprosthesis is indicated?]. Orthopade, 2000, vol. 29, no. 4, pp. 288-293. (in German) DOI: 10.1007/s001320050449

9. Salokhiddinov F.B., Karimov M.Iu., Tolochko K.P. Otsenka rezultatov lecheniia povrezhdenii kostei nizhnikh konechnostei sterzhnevym apparatom pri mnozhestvennykh i sochetannykh travmakh [Outcomes of multiple and combined bone injuries of lower limbs treated with half-pin fixator]. Genij Ortopedii, 2018, vol. 24, no. 1, pp. 13-17. DOI: 10.18019/1028-4427-2018-241-13-17

10.Meinberg E.G., Agel J., Roberts C.S., Karam M.D., Kellam J.F. Fracture and dislocation classification compendium. J. Orthop. Trauma, 2018, vol. 32, no. Suppl. 1, pp. S1-S170. DOI: 10.1097/BOT.0000000000001063

11. Otsenka iskhodov perelomov kostei oporno-dvigatelnogo apparata $i$ ikh posledstvii: instruktsiia. Utv. tsentr. In-tom Travmatologii i Ortopedii im. N.N. Priorova 15.11.83 [Assessment of the outcomes of fractures of the locomotor system and their consequences: instruction. Approved by Central Priorov Institute of Traumatology and Orthopaedics 15.11.83.]. M., TsITO, 1983, 11 p. (in Russian) 
12. Allakhverdiev A.S., Soldatov Iu.P. Problemy lecheniia postradavshikh s perelomami sheiki bedrennoi kosti (literaturnyi obzor) [Problems of treating the injured persons with femoral neck fractures (A review of literature)]. Genij Ortopedii, 2016, no. 1, pp. 90-95. (in Russian)

13.Markov A.A., Kuznetsov I.V., Sergeev K.S. Khirurgicheskoe lechenie perelomov sheiki bedra [Surgical treatment of the femoral neck fractures]. Meditsinskaia Nauka i Obrazovanie Urala, 2007, no. 6, pp. 28-30. (in Russian)

14.Talyshinskii R.R., Gadzhiev Sh.Sh. Osteosintez chrezvertelnykh i podvertelnykh perelomov bedrennoi kosti sterzhnevymi apparatami naruzhnoi fiksatsii u lits pozhilogo vozrasta [Osteosynthesis of transtrochanteric and subtrochanteric femoral fractures with half-pin devices for external fixation in the elderly subjects]. Novosti Khirurgii, 2011, vol. 19, no. 3, pp. 82-85. (in Russian)

15.Shagdurin V.A., Krasnoiarov G.A., Dorzhiev Ch.S. Lechenie perelomov sheiki bedrennoi kosti apparatom naruzhnoi fiksatsii [Treatment of the femoral neck fractures with an external fixator]. Vestnik Buriatskogo Gosudarstvennogo Universiteta, 2012, no. 12, pp. 72-74. (in Russian)

16.Sirodzhov K.Kh. Preimushchestva sterzhnevogo osteosinteza u bolnykh s sochetannymi i mnozhestvennymi perelomami opornodvigatelnogo apparata [The advantages of half-pin osteosynthesis in patients with concomitant and multiple fractures of the locomotor system]. Nauchno-Prakticheskii Zhurnal TIPPMK, 2014, no. 3, pp. 38-43. (in Russian)

Received: 12.05 .2020

Information about the author:

Fakhriddin B. Salokhiddinov, M.D.,

Tashkent Medical Academy, Tashken,t Uzbekistan,

Email: fb.doc@mail.ru 